\title{
Effect of limited access dressing on surface $\mathrm{pH}$ of chronic wounds
}

\author{
Pramod Kumar ${ }^{1,2}$, Thittamaranahalli Muguregowda Honnegowda² \\ ${ }^{1}$ Department of Plastic Surgery, King Abdulaziz Specialist Hospital, Sakaka 42421, Al-Jouf, Saudi Arabia. \\ ${ }^{2}$ Department of Plastic Surgery and Burns, Kasturba Medical College, Manipal 576104, Karnataka, India.
}

Address for correspondence: Dr. Pramod Kumar, Department of Plastic Surgery, King Abdulaziz Specialist Hospital, Sakaka 42421, Al-Jouf, Saudi Arabia. E-mail: pkumar86@hotmail.com

\begin{abstract}
Aim: Changes in the $\mathrm{pH}$ of chronic wounds can inhibit the optimal activity of various enzymes in the wound environment, thereby delaying wound healing. The aim of the present study is to monitor the effect of limited access dressing (LAD) on the $\mathrm{pH}$ on the surface of chronic wounds. Methods: A total of 140 patients with chronic wounds of more than 4 weeks duration were divided into two groups by simple randomization: a LAD group $(n=64)$ and a conventional dressing group $(n=76)$. Fifty-six participants (22 in the LAD group and 34 in the conventional dressing group) were lost to follow-up or withdrawn from the study. Results: In the LAD group $(n=42)$, the mean age was $38.3 \pm 10.56$ years (range: 12-60 years), and the mean wound size at the time of admission was $28 \mathrm{~cm}^{2}$ (range: $19-40 \mathrm{~cm}^{2}$ ). In the conventional dressing group $(n=42)$, the mean age was $35.3 \pm 14.0$ years (range: $17-65$ years), and the mean wound size at the time of admission was $26 \mathrm{~cm}^{2}$ (range: $18-39 \mathrm{~cm}^{2}$ ). Patients treated with LAD showed a significant decrease in the mean \pm standard deviation $\mathrm{pH}$ when compared with the conventional dressing group $(0.83 \pm 0.52$ vs. $0.41 \pm 0.26, P=0.048)$. Conclusion: LAD reduces the chronic wound surface $\mathrm{pH}$ to a level required for the optimal function of various enzymes. This could be a factor that exerts a beneficial effect on wound healing.
\end{abstract}

Key words:

Chronic wounds, limited access dressing, negative pressure wound therapy, wound surface $\mathrm{pH}$

\section{INTRODUCTION}

Chronic nonhealing wounds continues to pose a treatment challenge to the clinician. ${ }^{[1-3]}$ Several enzymatic reactions in the wound environment are governed by the wound $\mathrm{pH}$. Chronic nonhealing wounds may occur secondary to an elevated alkaline $\mathrm{pH}^{.4]}$ Very few studies have investigated the relationship between wound $\mathrm{pH}$ and the healing of chronic wounds. A study by Leveen et al. ${ }^{[5]}$ established that weakly acidic wound environments significantly inhibit protease activity and may potentially promote wound healing. A subsequent comprehensive review by Schneider et al. ${ }^{[6]}$ and Percival et al. ${ }^{[7]}$ showed that $\mathrm{pH}$ is

\begin{tabular}{|l|l|}
\multicolumn{2}{|c|}{ Access this article online } \\
\hline Quick Response Code: & Website: \\
\hline & www.parjournal.net \\
\cline { 2 - 2 } & \\
\hline
\end{tabular}

an influential factor in the healing process, as an acidic environment favors wound healing. The $\mathrm{pH}$ of the wound surface may change due to various factors including infection, oxygenation and topical applications of various dressing materials. Modulation of the wound $\mathrm{pH}$ may therefore change the direction of wound healing. There were no studies in the literature evaluating the role of negative pressure wound therapy in modulating wound $\mathrm{pH}$.

Limited access dressing (LAD), a relatively new technique that combines negative pressure and moist wound

This is an open access article distributed under the terms of the Creative Commons Attribution-NonCommercial-ShareAlike 3.0 License, which allows others to remix, tweak, and build upon the work non-commercially, as long as the author is credited and the new creations are licensed under the identical terms.

For reprints contact: reprints@medknow.com

How to cite this article: Kumar P, Honnegowda TM. Effect of limited access dressing on surface $\mathrm{pH}$ of chronic wounds. Plast Aesthet Res 2015;2:257-60.

Received: 30-01-2015; Accepted: 27-07-2015 
dressings, has been shown to have a positive effect on wound healing. ${ }^{[8]}$ The aim of the present study is to determine the effect of LAD on wound surface $\mathrm{pH}$.

\section{METHODS}

\section{Ethical issues}

This randomized control trial was carried out in the Burns and Plastic Surgery Department of Kasturba Medical College and Hospital, Manipal, Keanataka, India. The study protocol was reviewed and approved by the Institutional Ethics Committee. The study was conducted as per approved protocol after obtaining informed consent from all patients.

\section{Study design and randomization}

Two hundred and fifteen patients with chronic wounds of more than 4 weeks duration were screened in the study. Patients were evaluated for inclusion criteria (nonhealing chronic wounds) and exclusion criteria (collagen disorders, diabetes, leprosy, cirrhosis, HIV and pregnancy), and 140 patients were enrolled in the study. Simple randomization was performed (www.random.org; random number table was prepared) with assigned numbers and treatment sealed in opaque envelopes.

One hundred and forty patients with a mean age of $36.86 \pm 12.4$ years (range: $12-65$ years) were randomized and assigned to the LAD group $(n=64)$ or the conventional dressing group $(n=76)$ by simple randomization [Figure 1].
Of 140 patients, 56 participants (22 in the LAD group and 34 in the conventional dressing group) were lost to follow-up or withdrawn from the study. Of 42 patients in the LAD group, $22(52 \%)$ were women, and $20(48 \%)$ were men. In the conventional dressing group, of 42 patients, 18 (42.8\%) were women, and 24 (57.1\%) were men [Figure 1].

In the LAD group, the mean age was $38.3 \pm 10.56$ years (range: 12-60 years), and the mean wound size at the time of admission was $28 \mathrm{~cm}^{2}$ (range: 19-40 $\mathrm{cm}^{2}$ ). In the conventional dressing group, the mean age was $35.3 \pm 14.0$ years (range: 17-65 years), and the mean wound size at the time of admission was $26 \mathrm{~cm}^{2}$ (range: 18-39 $\mathrm{cm}^{2}$ ) [Table 1].

Patients in the LAD group were treated with intermittent negative pressure. ${ }^{[8]}$ In the conventional closed dressing group, patients were dressed daily with $5 \%$ povidone-iodine solution soaked gauze. The wounds of both groups were washed daily.

\section{Assessment of wound surface $\mathrm{pH}$}

The surface $\mathrm{pH}$ was measured by a $\mathrm{pH}$ paper strip (Merck, Mumbai, India) placed on the surface of the wound with care taken to ensure accuracy. ${ }^{[9]}$

\section{Statistical analysis}

Data obtained from both groups were analyzed using the Student's $t$-test SPSS, 15th version, SPSS Inc., Chicago. The data (mean $\pm \mathrm{SD}$ ) were compared between the two groups. A $P<0.05$ was taken as statistically significant.

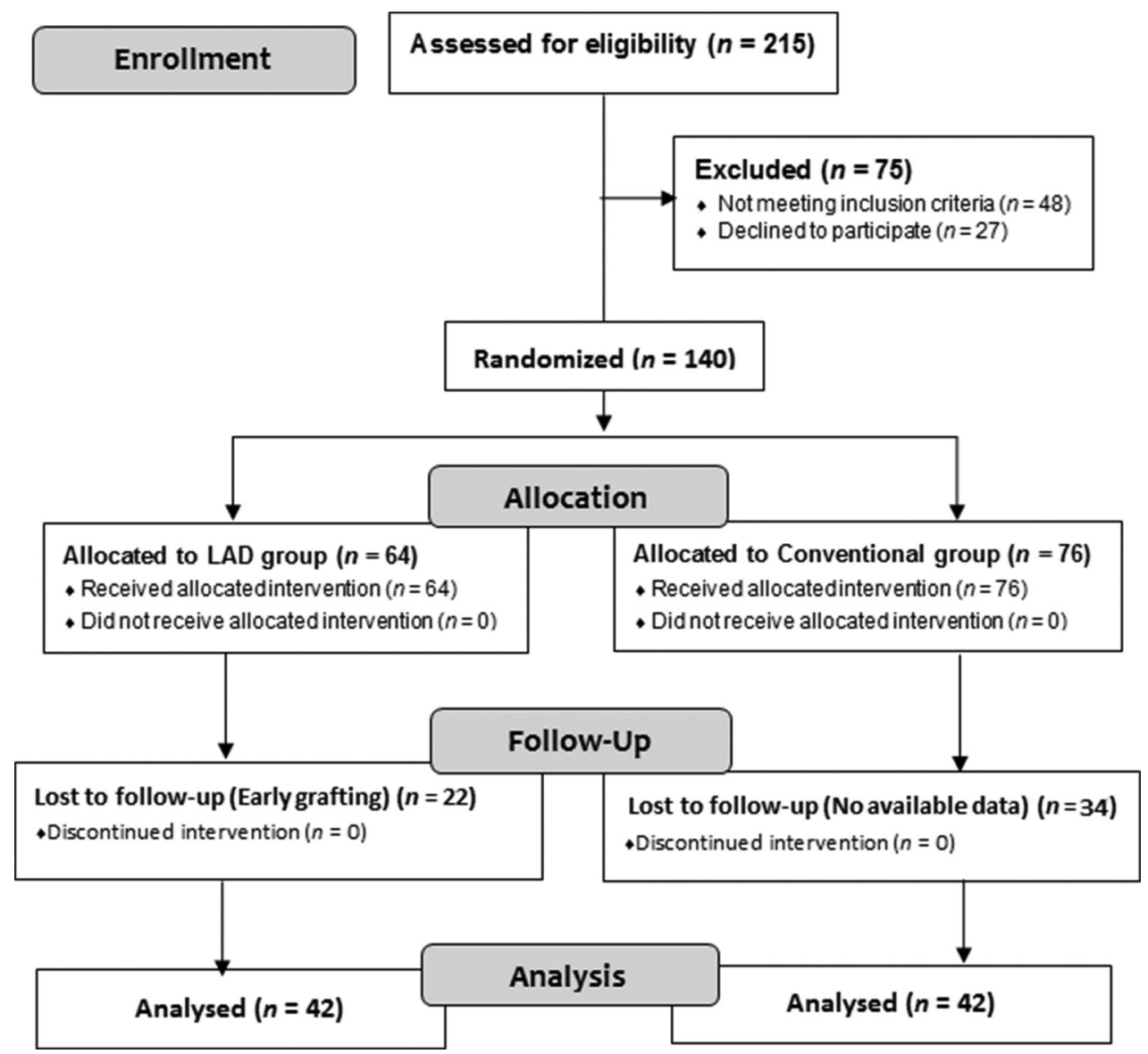

Figure 1: Consort flowchart 


\section{RESULTS}

In total, 215 patients were screened, 140 patients were randomized, of whom 64 were assigned to the LAD group and 76 to the conventional group [Figure 1]. Of the 56 participants, 22 in the LAD group and 34 in the conventional dressing group were lost to follow-up or withdrawn from the study. The results of wound surface $\mathrm{pH}$ in chronic ulcer patients of the LAD group as compared to that of the conventional dressing group shown in Table 2.

\section{DISCUSSION}

The acidity and alkalinity are measured by $\mathrm{pH}$ value, that is, $\mathrm{pH}$ is a measurement of the concentration of $\mathrm{H}^{+}$in the body. It ranges from 1 to 14 , with pure water at a $\mathrm{pH}$ of 7 to be considered neutral. Acidic solution has a $\mathrm{pH}$ of less than 7 and basic or alkaline solutions have a $\mathrm{pH}$ more than 7 . Body $\mathrm{pH}$ can be tested using litmus paper immersed in saliva or urine. Even a minor variation in the concentration of $\mathrm{H}^{+}$can alter the rate of many biochemical processes. Body $\mathrm{pH}$ can change secondary to diet, consumption of chemicals, exercise and various diseases altering the metabolism of body. Topical applications may change the body surface $\mathrm{pH}$. Wound healing is regulated by complex chemical processes mediated by various enzymes and hormones. Hence, various intrinsic and extrinsic factors may influence the $\mathrm{pH}$ of the wound environment, leading to alterations in the healing process. Therefore, events in wound healing including vasodilation, inflammation, release of oxygen into the wound bed, protease activity and the release and effects of bacterial toxins may be significantly influenced by the $\mathrm{pH}$ of the wound. The $\mathrm{pH}$ of body fluids and tissues is stabilized by various protein buffering systems. Hydrogen ions bind to protein molecules or bound hydrogen ions are released, changing their concentration in the body's tissues and fluids. Intracellular buffers such as hemoglobin in its

Table 1: Patient demographics and wound characterization at baseline

\begin{tabular}{lcc}
\hline & LAD group & Conventional group \\
\hline Number of patients & 42 & 42 \\
Age, years & $38.3 \pm 10.56$, & $35.3 \pm 14.0$, \\
(mean \pm SD, range) & $12-60$ years & $17-65$ years \\
Mean wound size $\left(\mathrm{cm}^{2}\right)$ & 28 (range: $19-40)$ & 26 (range: $18-39)$ \\
Female $(\%)$ & 52 & 42.8 \\
Male $(\%)$ & 48 & 57.1
\end{tabular}

SD: Standard deviation, LAD: Limited access dressing reduced form act as good buffering agents of the body. Hemostasis, inflammation, proliferation and remodeling are the four overlapping phases of wound healing. Altered or impaired healing of chronic wounds is the result of an interruption in the various processes of these four phases of wound healing. Changes in the $\mathrm{pH}$ of the wound surface may be induced by application of topical preparations that influence the cellular events in wound healing. Subjective evaluation of the wound bed is performed by clinicians when making clinical decisions regarding management. A simple system for monitoring wound $\mathrm{pH}$ may provide an objective method for clinicians when deciding upon the course of treatment. ${ }^{[10]}$

The $\mathrm{pH}$ environment of chronic wounds has been recorded within the range of 7.15-8.9.|11-13] Both acute and chronic wounds with an elevated alkaline $\mathrm{pH}$ have demonstrated lower rates of healing than wounds in which the $\mathrm{pH}$ is closer to neutral. ${ }^{[5,10,14]}$ Chronic wounds exhibit excessive breakdown of the extracellular matrix, and this occurs more readily when the wound has an alkaline $\mathrm{pH}^{[14,15]}$ which may contribute to nonhealing ulcers. A study by Greener et al. ${ }^{[15]}$ showed that every protease shows peak enzyme activity at certain $\mathrm{pH}$ levels, where the protein is broken down more rapidly than at other $\mathrm{pH}$ values. For example, cathepsins $G$ has peak activity at $\mathrm{pH} 7.0$, elastase at 8.0, matrix metalloproteinases 2 (MMP-2) at 8.0, and neutrophil elastase at 8.3. The shift of the $\mathrm{pH}$ in a wound environment from alkaline to acidic favors the production of healthy granulation tissue by decreasing the growth of bacteria and MMPs. ${ }^{[15]}$ The alteration of surface $\mathrm{pH}$ of wounds by the use of topical preparations has been used to promote healing. ${ }^{[16,17]}$ In the present study, the wound surface $\mathrm{pH}$ of LAD vs. conventional dressing on day 0 was (mean \pm SD) $8.33 \pm 0.35$ vs. $8.31 \pm 0.38$. On day 10 , the mean wound surface $\mathrm{pH}( \pm \mathrm{SD})$ in the LAD vs. conventional dressing group was $7.5 \pm 0.43$ vs. $7.9 \pm 0.47$. The decrease in the mean wound surface $\mathrm{pH}( \pm \mathrm{SD})$ after 10 days of treatment in the LAD group was $0.83 \pm 0.52$ while in the conventional dressing group, it was $0.41 \pm 0.26(P=0.048)$.

LAD is a newer method of dressing which combines the principles of both negative pressure and moist wound healing. It utilizes a definite intermittent negative pressure regimen of $30 \mathrm{~min}$ of negative pressure followed by a rest period of $3.5 \mathrm{~h}$. During the period without negative pressure, the LAD acts as a moist wound dressing. The wound bed preparation period has been shown to be reduced in LAD as compared to conventional dressings. ${ }^{[8]}$ Also, the percentage of graft take under LAD has been shown to be higher. ${ }^{[8]}$ LADs have been shown to

Table 2: Results of wound surface pH in the LAD $(n=42)$ and conventional dressing group $(n=42)$

\begin{tabular}{|c|c|c|c|c|c|c|c|}
\hline \multirow[t]{3}{*}{ Parameters } & \multicolumn{6}{|c|}{ Mean \pm SD } & \multirow[t]{3}{*}{$P$} \\
\hline & \multicolumn{3}{|c|}{ LAD group $(n=42)$} & \multicolumn{3}{|c|}{ Conventional dressing group $(n=42)$} & \\
\hline & Day 0 & Day 10 & Day $(0-10)$ & Day 0 & Day 10 & Day $(0-10)$ & \\
\hline Wound surface $\mathrm{pH}$ & $8.33 \pm 0.35$ & $7.5 \pm 0.43$ & $0.83 \pm 0.52$ & $8.31 \pm 0.38$ & $7.9 \pm 0.47$ & $0.41 \pm 0.26$ & 0.048 \\
\hline
\end{tabular}

SD: Standard deviation, LAD: Limited access dressing 
have a faster rate of healing for both chronic and acute wounds. ${ }^{[8]}$ In the present study, a significant decrease in the wound surface $\mathrm{pH}$ of chronic wounds $(P=0.048)$ was noted in patients treated with the LAD as compared with the conventional group. The lower $\mathrm{pH}$ may be one of the factors responsible for improved wound healing with LAD as experienced clinically. ${ }^{[18-21]}$ Lower systemic toxic symptoms in patients treated by LAD may be due to reduced activity of bacteria and bacterial toxins under the influence of a lower $\mathrm{pH}$.

In conclusion, the study showed a reduction in the wound $\mathrm{pH}$ in LAD treated patients as compared to those who received a conventional dressing treatment. Lowering the $\mathrm{pH}$ in chronic wounds may accelerate wound healing by reestablishing equilibrium in the wound bed.

\section{Financial support and sponsorship Nil.}

\section{Conflicts of interest}

There are no conflicts of interest.

\section{REFERENCES}

I. Callam MJ, Ruckley CV, Harper DR, Dale JJ. Chronic ulceration of the leg: extent of the problem and provision of care. Br Med J (Clin Res Ed) 1985;290:1855-6.

2. Nelzen O, Bergqvist D, Lindhagen A. The prevalence of lower-limb ulceration has been underestimated: results of a validated population questionnaire. Br J Surg 1996;83:255-8.

3. O'Brien JF, Grace PA, Perry IJ, Burke PE. Prevalence and aetiology of leg ulcers in Ireland. Ir J Med Sci 2000; 169: I I0-2.

4. Ye RC. The relationship of $\mathrm{pH}$ of the granulation tissue and the take of the skin graft. Plast Reconstr Surg 1957;19:213-7.

5. Leveen HH, Falk G, Borek B, Diaz C, Lynfield Y, Wynkoop BJ, Mabunda GA, Rubricius JL, Christoudias GC. Chemical acidification of wounds: an adjuvant to healing and the unfavorable action of alkalinity and ammonia. Ann Surg 1973; 178:745-53.

6. Schneider LA, Korber A, Grabbe S, Dissemond J. Influence of $\mathrm{pH}$ on wound-healing: a new perspective for wound-therapy? Arch Dermatol Res 2007;298:413-20.

7. Percival SL, McCarty S, Hunt JA, Woods EJ. The effects of $\mathrm{pH}$ on wound healing, biofilms and antimicrobial efficacy. Wound Repair Regen 20। 4:22: 174-86.

8. Kumar P. Exploiting potency of negative pressure in wound dressing using limited access dressing and suction-assisted dressing. Indian J Plast Surg 2012;45:302-15.

9. Shukla VK, Shukla D, Tiwary SK, Aqrawal S, Rastoqi A. Evaluation of pH measurement as a method of wound assessment. J Wound Care 2007; 16:291-4.

10. Gethin G. The significance of surface $\mathrm{pH}$ in chronic wounds. Wounds UK 2007;3:52-6.

II. Wilson IA, Henry M, Quill RD, Byrne PJ. The $\mathrm{pH}$ of varicose ulcer surfaces and its relationship to healing. Vasa 1979;8:339-42.

12. Tsukada K, Tokunaga K, Iwama T, Mishima $\mathrm{Y}$. The $\mathrm{pH}$ changes of pressure ulcers related to the healing process of wounds. Wounds 1992;4:16-20.

13. Romanelli M, Schipani E, Piaggesi A, Barachini P. Evaluation of surface pH on venous leg ulcers under allevyn dressings. In: International Congress and Symposium Series-Royal Society of Medicine, editors. Evidence-based Woundcare. Proceedings of a Conference Sponsored by Smith and Nephew; 1997 November, 17, UK. London: Royal Society of Medicine Press; 1998. p. $57-60$

14. Roberts G, Hammad L, Creevy J, Shearman C, Mani R. Physical changes in dermal tissues around chronic venous ulcers. In: Proceedings of the European Conference on Advances in Wound Management; 1997 November, 18-20. Harrogate, UK. London: EMAP Healthcare Ltd.; 1998. p. I04-5.

15. Greener B, Hughes AA, Bannister NP, Douglass J. Proteases and $\mathrm{pH}$ in chronic wounds. J Wound Care 2005; |4:59-6I.

16. Gethin GT, Cowman S, Conroy RM. The impact of Manuka honey dressings on the surface $\mathrm{pH}$ of chronic wounds. Int Wound J 2008;5:185-94.

17. Molan PC. Re-introducing honey in the management of wounds and ulcers-theory and practice. Ostomy Wound Manage 2002;48:28-40.

18. Kumar PP, Sharma A. The limited access dressing for damage control in trauma patients. Wounds 2010;22:188-92.

19. Sreenivas T, Nandish Kumar KC, Menon J, Nataraj AR. Calcific myonecrosis of the leg treated by debridement and limited access dressing. Int Low Extrem Wounds 2013; 12:44-9.

20. Friji MT, Mohapatra DP, Chittoria RK, Dinesh Kumar S, Ashokan A, Vijayaraghavan $\mathrm{N}$. Use of urine collection bag as an alternative of custom-made plastic bag for limited access dressing (LAD). J Soc Wound Care Res 2013;6:36-9.

21. Chittoria RK, Kumar P, Bajaj SP, Singh AK, Gupta DK. General clinical guidelines for wound management: redefining acronym SWCR.J Soc Wound Care Res 2014;7:2-7. 